\title{
The importance of Ljubljana's plot gardening for individuals, the environment and the city
}

This article examines the importance of Ljubljana's plot gardening in relation to three aspects: social, ecological and spatial. Plot gardening in a city, as a common urban practice, is comprised of several aspects, not only food supply, as is stressed in this text. As an informal social activity, it satisfies many individual needs and is related to the quality of life and living environment. It is also important when considering spatial values and preferences because in the process of studying plot gardening as a social phenomenon the cultural specifics and social importance of this activity for Ljubljana residents is being identified. Thus, with favourable conditions and management as well as monitoring of the activity, plot gardening is positive in numerous regards, not only for the plot users but also for the city and the environment as well because the green city system and a positive city image are important. Disagreements that arose due to issues of cleaning up plot gardens in Ljubljana required a suitable solution to the problems of plot gardening. Considering the facts and in order to prevent the problems that can arise from this activity, the importance of and justification for plot gardening is stressed, particularly concentrating on the advantages of the practice.

Key words: plot gardening, social phenomenon, allotment holders, spatial sociology, Ljubljana, Slovenia 


\section{Introduction}

When studying plot gardening in Ljubljana, complex matters must be considered. Due to the inadequate definition of plot gardening in the city plans and insufficient designation of areas intended for this purpose, the number of plot gardens spontaneously increased (especially between 1984 and 1995, after which the area and number of plot gardens decreased; Bole et al., 2009). The increased number and dispersion of plot gardens proved problematic in many ways. We mention just a few of them; namely, environmental problems, the spontaneous and dispersed occurrence of plot gardens, illegal use of space and usurpation, eyesores, and conflicts between plot users and municipal authorities due to the cleanup of certain (problematic) locations. These concerns are not only linked to the plot users' activities, but also to the actions of the people involved in the process of solving the problems of plot gardening.

In an urban environment, successfully balancing various citizens' interests is complicated and difficult, thus limiting the sense of individual identity. It is understandable that a city must balance differing interests within its means and also manage space with set policies. Individuals' use of space cannot be completely unhindered. Despite this, we find informal and spontaneous use of space nearly everywhere, and within more complex societies such use is even increasing. Plot gardening in Ljubljana expanded spontaneously and, because there were no real area definitions or regulations, it has persisted for a lengthy period of time on mostly illegally occupied land.

Modern trends aim at a qualitative shaping of built-up and open public space, which is connected to quality of life and is becoming an increasingly important aspect of space formation and management. One of the legitimate space uses in the context of urban green spaces is plot gardening, this being proven by the examples of cities in other countries. Marginalisation of this activity and waiting for it to gradually disappear are naive assumptions, whereas finding adequate mechanisms for problem-solving is vital in order for the city to function successfully and be environmentally sustainable. Consider an example of a group of plot users that protested the demolition and cleanup of "their" plot gardens through. This raises obvious questions: is having a garden within a city indeed so important; where can we observe its advantages; and why is cleanup seen as an invasion despite the fact that the majority of the plot gardens were illegal and penalties should then be expected? Answering these questions is not simple, and to explain the circumstances invoked and their consequences always puts us in an uncomfortable position. Lately, however, this activity has been experiencing change (cleanup, and designation and equipping of new allotment gardens), and it is reasonable to stress the importance of plot gardening in a city and the level of its operation.

The original hypothesis relates to the importance of plot gardening at three levels. It is important for society, and particularly for users, because it enables them to satisfy their needs. It is also not only about directly satisfying users' needs, but also has wider significance. Indirect benefits influence all citizens and are mainly expressed through environmental advantages and the positive influence these gardens have over the city. Plot gardening is important from the ecological point of view and the point of view of sustainable development. As regards the city, it is important from the aesthetic and economic viewpoint for quality residential space. In previous study of plot gardening, it was stressed that plot gardening was important for its users in terms of economics or just in that it existed. We seek to stress the importance of plot gardening from other additional aspects, significant for the society as well as the environment and the city. The importance that plot gardening has for the city in which it occurs has been overlooked the most. Namely, with proper implementation, plot gardening can have many positive effects, although negative effects are what is stressed most often from an environmental perspective. We are aware that the problems concerning plot gardening mentioned in the introduction should not be neglected, yet they are not the main element of this discussion and therefore will not be discussed in depth. This article stresses the advantages of allotment gardening in terms of the three aspects mentioned. At the same time, we want to stress the importance of a suitable and professional approach to solving the problems of plot gardening, so that its potential advantages might instead be shown.

\section{Definition of plot gardening}

The reasons for plot gardening originated from the social, economic and leisure needs of persons living in an urban environment. First, it appeared in industrialized central European countries and then spread to all developed countries (Jamnik et al., 2009). The main characteristic of plot gardening is the fact that it is multifunctional and is related to several urban sectors, something that is explained later in this text. Plot gardening is included in and used by the urban (economical and ecological) system (Mougeot, 2000).

In defining plot gardening, creating a strong conceptualisation is difficult. On the basis of experience from other countries, the phenomenon of growing food and plot gardening in urban environments has been defined in a wider sense than in Slovenia, where it is defined in the Decree on management and lease of allotment gardens (Sln. Odlok o urejanju in oddaji vrtickov $v$ zakup) as a "leisure activity ... with the purpose of 
non-commercial food production for one's own consumption" (Ur. 1. RS, no. 28/2009: 4014). According to this definition, plot gardening in Ljubljana, in its narrow sense, is different from other types of plot gardening. Food production for the market is not allowed, and neither is stockbreeding or the presence of any animals. In contrast, Luc Mougeot defines urban agriculture in a much broader sense, namely as industry that includes numerous activities and does not mention trade per se, but distribution of "food and non-food products" (2000: 10). According to him, this can comprise formal trading as well as distribution within an informal users' network. He does not explicitly mention individual activities, but, with this definition, includes all possible options. Only definitions of urban agriculture in their broader sense include food production and fruit trees, as well as various kinds of stockbreeding, medicinal herbs and ornamental plants (Jacobi et al., 2000). In the context of this activity, Mougeot (2000: 10) also defines "(re-)using largely human and material resources, products and services found in and around that urban area, and in turn supplying human and material resources, products and services largely to that urban area." By this standard, various activities of individuals and households are taken into account in the process of obtaining a food supply and generating income. In addition, the activity is also considered an integral part of the urban system. The division of urban agriculture from rural agriculture is reflected precisely in the integration of the former into the urban ecosystem.

The term "urban agriculture" is emphasized and separated from the concept of plot gardening because it is defined in a much broader sense. Plot gardening, as known in Ljubljana, is among the three types or sub-categories of urban agriculture as defined by the RUAF Foundation Organisation (Internet 1). Types of urban agriculture are defined by the RUAF as the following:

- Micro-farming in and around the house/homestead: food and herb production as well as animal breeding for subsistence reasons, leisure, and (organic) food preferences, which is carried out on balconies, windowsills, or roofs, or in cellars, as well as in courtyards that belong to blocks of flats;

- Community gardens: allotment gardening in public or semi-public areas for subsistence reasons, leisure and dietary preferences;

- Institutional urban agriculture: allotment gardening at schools, prisons and hospitals, in which the main aim is to provide food for the residents or inmates;

- Small-scale (semi-) commercial horticulture: the purpose is commercial production and consumption by the urban poor and small-scale peri-urban farmers; food production, mainly vegetables, but also herbs and fruit;
- Small-scale (semi-)commercial livestock and aquatic farming: the purpose is commercial production and consumption by small-scale peri-urban farmers and the urban middle class; production of food products;

- Specialised urban agriculture and forestry production: activity of people involved in various projects in the production of mushrooms, potted plants and tree nurseries exclusively for commercial production and with a strong tendency toward further intensification and technical support;

- Large-scale agro-enterprises: large peri-urban farms with employed workers; commercial food production, an important role in local food supply of the city;

- Multifunctional farms: small-scale family or large peri-urban farms with employed workers; commercial food production and the supply of some other service activities.

Plot gardening in Ljubljana can be categorised as microfarming within and around residential areas, as unregulated community gardens (the most frequent and at the same time the most problematic form of plot gardening in Ljubljana) and as institutional urban agriculture, whose practice is being increasingly abandoned. Plot gardening thus does not include gardens that are a component of individual dwellings or terraced houses, but only the aforementioned types (Figure 1). The problem of plot gardens also relates to the unregistered status of the majority of the plot gardens in Ljubljana, presenting a potential risk to the environment. They are specifically regarded as an aesthetic degradation of the city's image, although they satisfy the needs of their users and are thus socially important.

It has been documented that plot gardening in the US and Europe is not only a lower-class activity or the activity of rural immigrants, but also includes high-income households and older citizens. Regarding location, plot gardens are mainly fo-

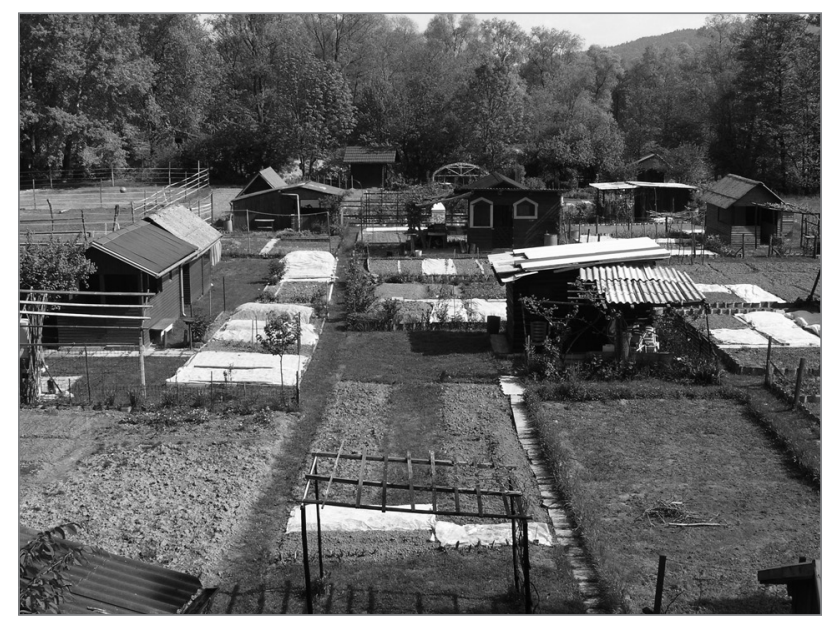

Figure 1: Plot gardens in Ljubljana (photo: Aleš Smrekar). 
und in open areas in the relative vicinity of the user's dwelling either informally or according to an agreement with the formal owner of the premises. This category primarily includes personal consumption, distribution of surplus among relatives and neighbours, and also (in certain cases) trading of the surplus in local markets. These characteristics are consistent with plot gardening in Ljubljana, considering that trading and animal breeding are not common among plot holders because they are not allowed.

\section{The importance of plot gardening from the individual user's perspective (social aspect)}

Public green spaces, which include plot gardens, have been included in the city structure as an "equal, irreplaceable spatial element" (Simoneti, 1997: 19). The social function of green spaces, which significantly influences the quality of living, is being introduced. Residents are protectively critical of any activities that affect public green spaces because interest in their active use is increasing. Therefore, planning the use of physical space is needed so that areas without control or maintenance are not exposed to changes in land usage practices (Simoneti, 1997: 19). An additional problem, specifically noticeable in the case of Ljubljana, relates to non-urbanised areas, which are experiencing spontaneous development of unregistered activities, especially plot gardening (Smrekar, 2007). The importance of urban green spaces is confirmed by the fact that green systems in large European cities are increasing in size annually due to the growing needs and demands of their residents (Simoneti, 1998). A surprising fact is that modern cities have not eliminated food production from the sphere of urban social activity and that plot gardening is an established_practice to the extent that it exists in almost all metropolises of developed countries as well as in developing countries. Plot gardening is not a remnant of the past because interest and involvement in this practice is increasing with the expansion of the cities. It is also not only a part of the immigrant culture, those coming from rural areas to the city that are expected to abandon their rural habits (Internet 1). Plot gardening in a city is an integral part of the urban system and now it is necessary to determine and regulate areas suitable for this activity.

If plot gardening is considered within the context of urban green spaces, as it is defined in the new spatial acts, we cannot overlook the need of urban citizens to be in close proximity with nature, a dynamic noted at several levels. Nature's presence in the city is, according to Drago Kos, only a "more or less sufficient substitute, hardly satisfying the basic need for authenticity, which the need for nature basically is" (2007:
158). A city as a cultural space cannot replace the natural space, yet it can attempt to integrate it within the urban system and make it a useful part. The city can in some sense replicate the natural space and thus to some extent satisfy the urban citizens' need for it. In the case of Ljubljana, we can claim that the need for nature's presence is even stronger. The reason is that in a small city like Ljubljana, located in the immediate vicinity of the countryside and in which we find an extremely high percentage of urban green space, the need for nature's presence is constantly stressed. Considering a city's limitations, however, these needs are impossible to completely satisfy.

This leads us to the conclusion that we must also consider $\mathrm{cul}$ tural patterns within Slovenian society as special factors when looking at the importance to garden-plot users. In Slovenia we have a "cultural identification of the Slovenian people with the countryside" (Uršič \& Hočevar, 2007: 59) and we can claim that plot gardening is about linking the Slovenian urban and rural ways of life. Plot gardening is an expression of the fact that urban dwellers want to preserve a unique link to the countryside with (according to its characteristics) rural practices being used in urban space. In the case of plot gardening in Ljubljana, this social phenomenon is linked to or explained by the values related to the use of space and spatial preferences. $^{[1]}$ Considering the prevailing rural ideology in Slovenia, the importance of plot gardening from a social perspective is explained in this manner. We can observe the persistence of the users as regards cultivation, the influence of traditions, for example in gardening, transferred from one generation to another and also the influence of the "home country" ${ }^{[2]}$ as one of the practical ideologies relating to individuals' attachment to their garden plots. Anti-urban values demonstrate the negative attitude of the majority towards city life, and preferences regarding the desired place of living are mainly related to the countryside. We can also explain plot gardening as a form of adaptation to urban residential space in the cases where attachment to the countryside is evident. The cultural tradition of food production and preferences about living with this possibility are evident from the research findings. 65\% of those interviewed answered the question "Where would you prefer to live if you had a choice?" with the answer, "A house with a garden in a residential neighborhood" (Hočevar et al., 2004; Figure 2). Plot gardens can thus present a counterbalance to a dense spatial arrangement because the majority of plot users (59.3\%) live in a block of flats or a high-rise, as shown in Figure 3 (Jamnik et al., 2009).

Taking into account studies from other countries, we can conclude that there are several social aspects to plot gardening. We have determined its many purposes, in addition to the most obvious, which is food supply. The differences between the 


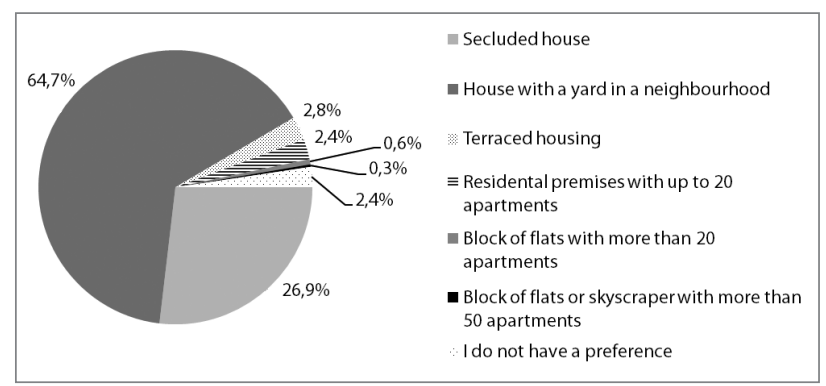

Figure 2: Living preferences (source: Hočevar et al., 2004).

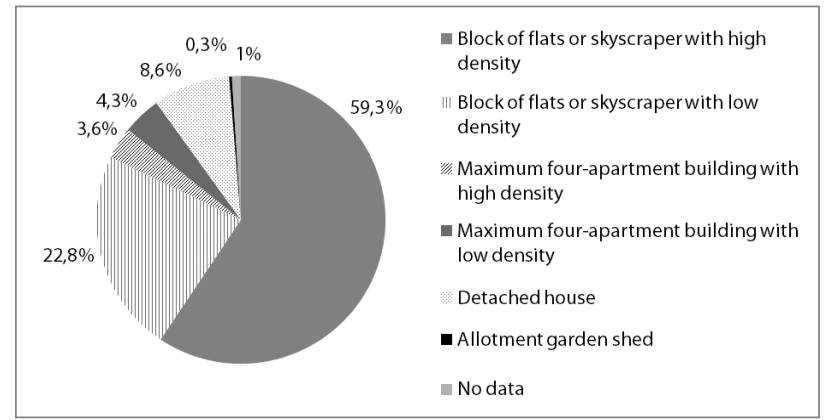

Figure 3: A typical plot users' dwelling unit in Ljubljana (source: Jamnik et al., 2009).

developed and developing countries are considerable and are mainly reflected in the reasons people undertake this activity and also in the needs that plot gardening satisfies. For developing countries, plot gardening represents an important strategy for survival, and is therefore encouraged and the conditions for its performance improved. For the developed countries, an important aspect is recreation and leisure time, although those attributes are important in both cases. The urban population is involved in gardening and farming activities in cities where the possibilities for it are created; namely, political and economic factors encourage this activity (Nugent, 2000). Well-regulated and favourable conditions can be identified in certain developing countries where plot gardening may represent an important economic component as well as survival strategy. Havana is one example where urban agriculture is being encouraged (Chaplowe, 1996). This is also true of Japan, where local authorities are creating and offering new measures for preserving plot gardening in the cities (Tsubota, 2007). The encouragement of plot gardening in cities has usually come from the communities; that is, individuals, social groups or non-governmental organisations (Smit et al., 1996). In developed and highly urbanised cities, plot gardening typically faces obstacles, partly due to the desire for privatisation of now-deserted areas where plot gardens had once expanded, and partly due to the need for more profitable use of these areas (as in the case of New York City). Consequently, the reality of plot gardening is as a transitional use of space because the activity must often give way to new construction or other public programmes, which is the case in Slovenia. The opportunities for plot gardening are now defined in the latest regulation (e.g., Figure 4). There are some exemplary European examples of protection of areas intended for plot gardening and managing them; for example, Berlin, Vienna and London (Petts, 2001; Jamnik et al., 2009). In Slovenia, the importance of plot gardening and its effects on the city's residents has mostly been overlooked. It was only upon realising how strongly plot gardening has become a part of the society and how linked it is to societal values that attention was given to regulating and defining plot gardening as one of the legitimate uses of physical space.

Among the important social advantages of plot gardening, Rachel Nugent (2000) lists economic diversification, household economic benefits and culture-specific behaviour. Cooperation of garden-plot users with regard to exchange of produce or waste is also common (Jacobi et al., 2000; Mougeot, 2000), indicating the establishment of community as well as social solidarity and social cohesion. Garden-plot users thus, among other things, search for opportunities for social interaction within this informal activity. At its best, plot gardening in urban environments replaces city dumps, gives the elderly a sense of purpose and respect, recycles household waste, produces food, increases environmental awareness and much else (Bourque, 2000; Internet 1). Although some of these results are difficult to observe, especially if seen as direct consequences, they nevertheless have a certain value. In Ljubljana there is a case of an area (by the Sava River) where garden-plot users first cleaned up the dump site and then arranged their own plot gardens.

The social role and importance of plot gardening in a city are reflected in increased food quality, better eating habits and potential higher food quantity for households taking part in this activity, by either direct or indirect means, which is especially important for the lower social strata. Plot gardening often presents an additional source of income when trading products or

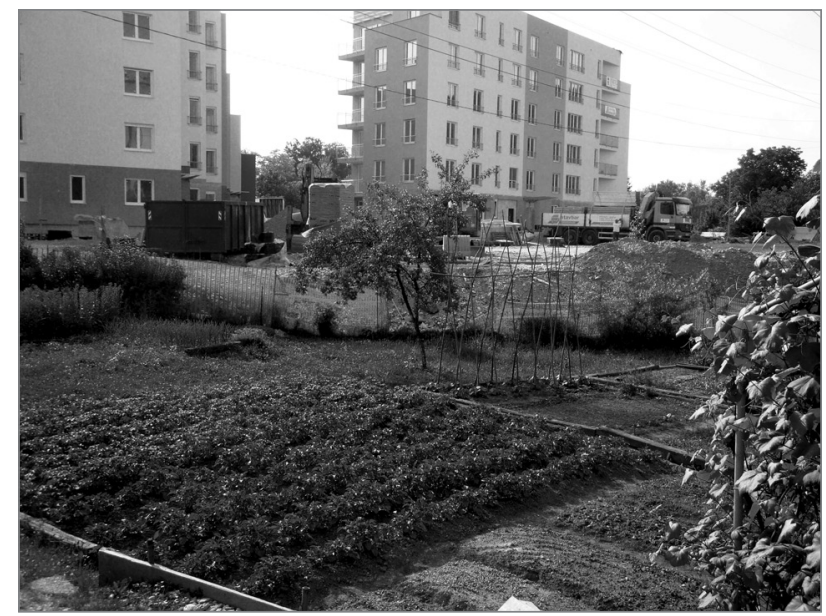

Figure 4: Plot gardens in the immediate vicinity of a construction site (photo: Karmen Bukvič). 
generating income and thereby saves money on food. Examples from other countries also stress the encouragment of involvement by certain typically marginalised social groups (such as immigrants, the handicapped, the unemployed and others). Urban agriculture thus adds a "complementary strategy" to decreasing poverty and food scarcity in urban environments (Internet 1), and is related to many other aspects. By explaining the needs that can be satisfied by plot gardening, we can also explain the importance of plot gardening's influence over the quality of people's lives and its considerable social importance (Simoneti et al., 1997):

- Psychological needs, which comprise direct contact with nature, the possibility of changing and influencing one's own environment, the aesthetic pleasure involved in creating and managing, and in part the need for ownership. We can also include it as a way of life, which, according to Mirjana Ule (1998), is not something necessary for survival, but nevertheless necessary for an individual's positive self-image. Because plot gardening reflects a certain way of living, it may satisfy those psychological needs. When listing these needs, we stress the positive aspect in monitoring the results of the garden-plot user's work and the importance of being a primary producer; that is, individuals that enjoy the fruits of their labour directly.

- Social needs, which mainly include socialising, interaction with other users and joining in groups or organised forums such as plot gardeners' associations. With regard to social needs, spare time is also important because plot gardening as an informal and supplementary utilitarian activity is a leisure-time activity.

- Physical needs relate to recreation, relaxation and rest.

- Existential needs basically relate to the economic aspect; namely, conventional or organic food production and supply, which saves on household expenses. It thus relates to the quantity and also the quality of the food produced for households performing plot gardening.

- Health needs, which relate to recreation in contrast to occupational (physically) non-active work (Vastl, 2000). Garden-plot users themselves stress the importance of this with regard to physical activity and psychological advantages. In the social networks established within the plot gardens, we can also stress the need for social support, which is proven to have influence as protection against stress and as a factor in having a good state of health (Cobb, 1976, cited in Hlebec \& Kogovšek, 2006). Health is indirectly reflected in the improvement of environmental conditions, which influence people's health.

Dealing with the need for aesthetic expression, Maja Simoneti et al. stress that both gardening and building the structures associated with plot gardening create opportunities for indi- viduals to take pleasure in "the sense of creativity and in experiencing their own work" (1997: 7). We can talk about a unique aesthetic experience as satisfying users' creative needs, although this can also be "the most obvious and disturbing characteristic of certain garden-plot areas" (Simoneti et al. 1997: 18). This fact is mentioned due to the prevailing negative attitude toward garden-plot areas because plot gardens are seen as an unnecessary obstruction to the visual aesthetics of the city.

Satisfying these needs is, in a way, the main social importance of plot gardening and at the same time represents the most important positive effects for the individual. The social importance of plot gardening in the cities of developed nations is shown through physical as well as psychological relaxation and through food production. Moreover, low-cost leisure opportunities, which can present a basis for micro-educational and profitable projects for young people, are also important (Internet 1). The importance of plot gardening increases in times of crisis (e.g. riots, natural disasters, and other disruptions). In such times people resort to this practice due to poverty, as was the case in Sarajevo and Baghdad (Smit et al., 1996).

According to the findings of the study Vrtickarstvo $v$ Mestni obcini Ljubljana kot vir onesnaževal v tleh, pridelani hrani in podzemni vodi (Plot gardening in the Municipality of Ljubljana as a source of soil, home-grown food and groundwater pollution), only a small percentage of Ljubljana residents are involved in plot gardening. They choose it more as a means of recreation and relaxation, as an opportunity to satisfy the need for contact with nature and as an opportunity to grow healthy food than as an economic necessity. According to Maja Simoneti et al. (1997), the importance of plot gardening as a significant economic activity in cities is not stressed enough. Although the economics of plot gardening in cities is important, in the case of Ljubljana a question arose regarding the economic component, especially emphasized during cleanup of the area. An illustrative example was the equipment used by certain plot gardens, which were more like a range of holiday homes. We cannot view garden-plot users as being economically deprived. In our opinion, the majority of gardenplot users combine various motivations; specifically, leisure, recreation and economics. The findings of the research show that only $9 \%$ of the garden-plot users claim that their plot is an important economic component for them, or that they use it for food production for subsistence reasons (Jamnik et al., 2009) (Figure 5). The economics are expressed at different levels, not only from the perspective of economic advantages for the individual, but also regarding economic advantages for the city. The economic nature of plot gardening is also evident in reducing the costs connected with food provision in urban areas, and in economic development, where it creates jobs, especially in poor cities. 


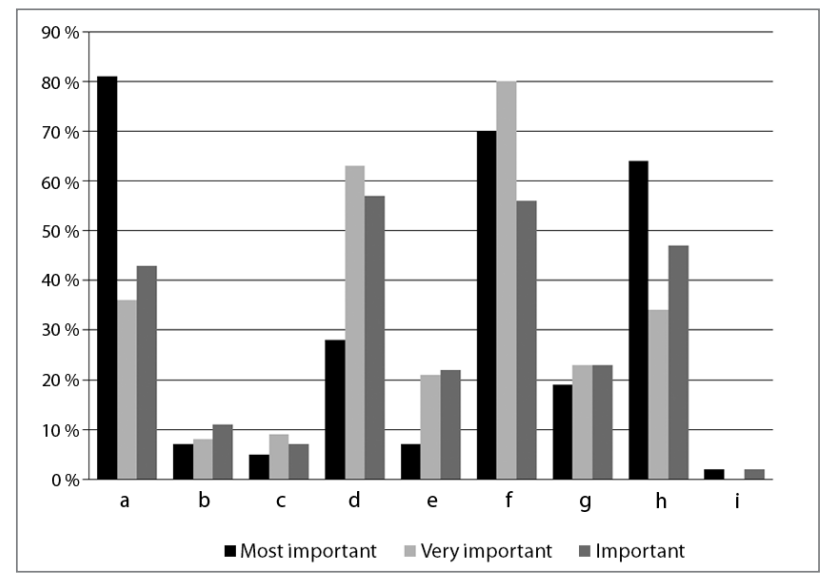

Note: a) direct contact with nature; b) desire for active use of urban green spaces; c) experiencing creativity, aesthetic pleasure; d) physical activity; e) spending spare time with family; f) recreation, relaxation; g) food production to reduce living expenses; $h$ ) production of healthy food; i) other.

Figure 5: The main motivations for plot gardening among Ljubljana garden-plot users (source: Jamnik et al., 2009).

During the cleanup of the garden plots in Črnuče, which caused a great deal of dissatisfaction among garden-plot users, the importance of the economics of plot gardening were stressed. Because this subjective estimation cannot be overlooked, it must be considered in redefining plot gardening and in determining the priority criteria with regard to acquiring use of a garden plot. The income of a household, in terms of a percentage of average net salary, is used as the priority criteria in assigning lease of allotment gardens. In addition, the need for plot gardening due to the economic crisis is being increasingly stressed, so we cannot claim with certainty which motivational factors currently prevail. The fact that economics and survival are not the most important factors, as is evident from the results of the research, should not play a role in whether to consider allotment gardens as part of city planning, or in determining the importance of allotment gardening for its users or for city residents. After all, allotment gardening combines several positive effects, significantly influencing the quality of peoples' lives in general. The following sections consider the indirect effects and advantages for the non-users of plot gardens; for example, the question of usefulness and the importance of garden-plot areas to non-users or other users of public green spaces. Plot gardens, after all, differ from other public green spaces (parks, recreational areas and others), which are intended for and available to everyone.

When studying how plot gardening activity and areas are defined in the new allotment gardening policy (Decree on the management and lease of allotment gardens [Sln. Odlok o urejanju in oddaji vrtičkov $v$ zakup] and Regulations for allotment garden area management in the Municipality of
Ljubljana [Sln. Pravilnik za urejanje obmocij vrtičkov v Mestni obcini Ljubljana]), we observe another important dynamic in studying plot gardening as a social phenomenon: the transition from reflexive spaces into more instrumental spaces. If we consider the elements of these two types of space, we see that the former situation expresses reflection, enabling the realisation of the individual's way of life. Listing only a few characteristics of the two forms, we can observe a typical characteristic of reflexive spaces to be a variety in practice (Hočevar, 2000), whereas in the case of instrumental spaces much standardisation is observed. Reflexive spaces are also defined by distinction between the systems and an explicit individualisation in the transformation process. In the case of instrumental spaces, the situation is the exact opposite. The latter are defined by universalities, with transformation processes that are defined more by globalisation. Thus, instrumental spaces are homogeneous and universal, whereas reflexive spaces reflect heterogeneity and particularity, which is (or was) evident in the garden-plot areas of Ljubljana. In reflexive places, we also detect expressiveness - namely, symbolic-aesthetic expressiveness. Before the cleanup processes began, garden-plot areas had expressed all the characteristics of reflexive space, which was a consequence of the lack of regulation. With enforcement and compliance to the new legislation, the regulations on plot gardening will become standardised with regard to visual characteristics and the use of the areas, and will thus reflect characteristics of instrumental spaces. If we compare Ljubljana's plot gardens with the plot gardens of other metropolises of the developed world, the Ljubljana garden-plot area will become comparable with regard to visual appearance, especially if we take into account that in instrumental spaces the process of transformation is determined by globalisation.

The decline in the reflexive nature of garden-plot areas is stressed because of the limited activity of the users, the fact that plot gardening will become legal and that the areas will be legalised and regulated by city operators. It is important that different criteria for acquiring the rights to use a garden plot have been set. If we consider that social status is a priority criterion, this means that plot gardens will be acquired by users to whom plot gardens represent an economic necessity and less as a factor of self-realisation typical of reflexive spaces. An additional item that illustrates this hypothesis is the high level of dissatisfaction expressed by the existing garden-plot users over the determinations of plot gardening for the future (aesthetic incidence, size, price etc.), which do not allow for individual expression. This does not mean that some informal plot gardens will not be re-established, but there is the tendency toward abolishing them, although the regulation mechanisms have so far proved inconsistent.

The provisions regulating plot gardening include standardisation as well as visible and general uniformity of garden-plot 
areas, stressing the rigidity of the regulatory conditions. This basically means that there are not many options left for the individual. The garden-plot users' reproaches regarding this uniformity of allotment areas can be understood by considering Zdravko Mlinar's thesis, in which he claims that exaggerated uniformity is an "impractical blockade that prevents even the most harmless enforcements of individual initiative and diversity of available resources" (1993: 432). Such uniformity can contradict the tendency towards preserving landscape identity. Simoneti et al. (1997) suggest that in more permanent allotment garden areas, where putting up a tool shed is allowed, for example, design regulations should not prevent individual expression in individual allotment gardens because the authors claim that these areas present an opportunity for expressing creativity in space management. Adaptation of an individual to the urban environment through various means of beautification and the possibility of influencing the environment can be important. Enabling plot gardening in the cities may result in lower numbers of secondary residences and dispersed buildings in the suburbs and countryside because it enables the use of rural practices and genuine rural spaces in a city. For some people, plot gardens offer an extension to their home, and some were even transformed into holiday cottages; efforts are therefore being made to eliminate these because they were never the intended purpose of garden plots. This is why suitable regulations and equipping the area are so important. Enabling plot gardening leads to a higher quality of life for urban residents.

\section{The importance of plot gardening from an environmental perspective}

Plot gardening is a part of the ecological system. Due to the remnants of pesticides and heavy metals in the soil and in the food produced, as well as pollution of groundwater, plot gardening presents a threat to people's health as well as for the environment (Jamnik et al., 2009). Negative environmental effects that may originate from plot gardening include eyesores, soil erosion, destruction of vegetation, soil sedimentation, depletion of water resources and pollution of natural resources (water, air, soil). Other disadvantages that need to be mentioned are the illegal use of land and water and crop theft (Mougeot, 2000; Nugent, 2000). In Ljubljana, we are dealing with other problems that exceed the extent of the environmental risks originating from plot gardening. Within this context are uncontrolled expansion, unprofessional choices of location (those not suitable for gardening) and (improper) use of various pesticides that then pollute natural resources. The situation that results can threaten garden-plot users or produce consumers because the crops were produced in areas where the soil is of questionable quality. Their vicinity around heavy traffic routes, waste dumps and other degraded areas is thus problematic.
In Ljubljana not only was various gardening activity performed, but also unlawful construction, the use and disposal of contaminated materials, and inadequate management of litter disposal and sanitation. Consequently, the negative effect on the environment in certain areas was much greater.

For environmental reasons, these problems indicate the necessity and importance of regulating plot gardening. In addition, the majority of research stresses that plot gardening, which is intended for providing for oneself, should not be based on the use of agrochemicals or should use smaller amounts of them (Mougeot, 2000; Petts, 2001; Jamnik et al., 2009). The importance of urban green spaces relates to the functions that these areas fundamentally have, regardless of human needs. This means that the purpose of a city's green system is to have a specific ecological role, so that different species can move between the natural and urban environment (Kučan, 1994). The purpose of plot gardening is not only urban food production because community-based or individual food production meets a wider range of needs for the urban population, but also sustainable urban development and environment protection (Jacobi et al., 2000). Sustainable urban development in relation to plot gardening appears in several studies that stress the social, economic and environmental aspects of sustainable development. It is also important that urban food production, that which is intended for urban consumption, substitute for food brought in from the countryside or imported from abroad. It can then contribute to a greater degree of self-sufficiency for a city with regard to the food system.

Among the advantages that plot gardening or urban farming can have for the environment, we can recognise general advantages of the green city systems and specific advantages that originate directly from plot gardening: greening the city, improving biodiversity, improving air quality, decreasing the heat of the city, improving microclimates, decreasing the amount of city waste and reusing organic waste and wastewater for plot gardening (Deelstra \& Girardet, 2000; Jacobi et al., 2000; Petts, 2001). This would then decrease the ecological footprint. If we explain these important aspects in detail, we need to mention that a growing city increasingly produces wastewater and organic waste. Allotment gardening presents a constructive solution because it uses urban waste as productive sources in its own activity. Although plot gardening within a city is usually seen as non-hygienic, it can be a potential means of improving the city's hygiene through the reuse of waste. Improved city waste management presents a transition from a problem to a productive solution. Plot gardening also has a positive influence in making the city green and cleansing its deserted areas, which can then become part of a builtup area, which has an additional positive effect on the city's 
microclimate. Because degraded open and deserted areas of the city often serve as "illegal waste dumps" and "places of crimes and health problems" (Internet 1), the transformation of such areas into productive green spaces is recommended. An important aspect to consider is how food is increasingly catalysing environmental awareness as people take action in that direction and "think before they swallow" (Petts, 2001: 10). In general, this trend reflects the interest in organic food and its increased consumption.

According to Drago B. Rotar (1981), urban green spaces are a dysfunctional supplement to utilitarian activity and are intended instead for leisure-time activities and recreation because they are not necessary for production or communication within a modern socio-economic system. This thesis adapts the prevailing perception of green city elements as unnecessary, although with the development of modern urban agglomerations, nature in the city has acquired a special place and function in the sense of satisfying certain vital needs of the individuals that live there. Public green spaces are thus understood in the context of individuals' quality of life. The problem in planning and making necessary investments to execute those plans arises from this assumption about green spaces being a dysfunction, mainly an economical or consumer dysfunction. In spite of all this, the need for cities, which develop in cohabitation with nature (the case of Ecocity builders; Internet 2), to include and protect natural spaces and strive towards sustainable development is increasing. Studies stress that "green and pleasant cities attract investment" (Petts, 2001:15), and this argument is important in defending the preservation of the open green spaces. Because money needs to be invested into long-term effective regulation and into environmentally sustainable land for plot gardens, it needs to be stressed that poor regulations and unfavourable conditions for this activity by the city managers will not attract candidates, and will consequently lead to a decrease in the need for plot gardening. That decreased need is not an argument for the preservation of urban green spaces, but is rather an argument to define these areas for other purposes. When portions of green space become building land, their purpose is ultimately changed. The key to creating the positive effect that plot gardening has on the environment is especially regulation of this otherwise informal activity. It is necessary to support the planners and suitably define this activity as well as correcting management of natural resources. Management of plot gardening, which can have a potentially negative effect on the users and the natural entities if carried out incorrectly, is thus absolutely necessary. Not only a degree of regulation of this informal activity, but a professional choice of locations that are most suitable for plot gardening from the ecological perspective and in terms of food production. It is important that we be aware of the fact that regulated plot gardening of- fers many more environmental advantages than risks. Adequate definition of the areas included and correct management of the environment can contribute to this a great deal.

\section{The importance of plot gardening from the city perspective}

In addition to the importance that garden plots represent to the city residents and the environment, the importance to the city itself is to be stressed. As a vital part of public green spaces, garden plots complement the green system and recreational potential. They also play a significant role in helping create the city image (Simoneti et al., 1997). Allotment gardens differ from other green areas of the city mainly intended for recreation or with an aesthetic purpose because the purpose of garden plots is also productivity. They represent (with more or less importance) an economic component to the individuals using them. Due to space-related problems, such as the expansion of plot gardening in chosen areas, and design problems, problems which led to non-acceptance of the activity by the majority of the public, suitable management and a solving of problems is needed, especially as regards the city's benefit.

Ana Kučan (1994) stresses the morphological role of the urban green spaces as a visual enrichment of a city's appearance. Taking this into account, we can claim that the aesthetic appearance of a city is also important because it influences the construction of the city and the cleanup of degraded sites. As Kos (2008) claims, it is the quantitative aspect of the green areas that determines the vitality and "health" of a city, the qualitative aspect being of secondary importance. This theory is, however, applied to other kinds of green city areas, whereas plot gardening is an activity that (as an agricultural activity) makes use of natural resources, is productive and thus can represent a threat to area resources. With plot gardening, the qualitative aspect is more important for the sake of the environment and a city's appearance. It is important that a city offer a sufficient number of allotment gardens in order to prevent their spontaneous emergence.

The established plot-gardening areas in Ljubljana have often been the subject of negative criticism due to their visual appearance and having been seen as an eyesore for the city. Allotment holders themselves evaluate the planned plot-gardening areas negatively because of their aesthetic insignificance and their uniformity. The appearances of garden plots and also the city's appearance are important parts of the problem, important in determining the location of future allotment gardens and the regulation of those that emerged spontaneously. As emphasised by the city authorities, "allotment gardens ... do not belong 
in the city centre, in visibly exposed locations, in the vicinity of cultural heritage areas or cemeteries" (Internet 3). By changing the location of the allotment gardens and removing them from certain problematic areas (e.g., Žale Cemetery), we observe that there is the tendency towards pushing them out of the area of social perception. In determining new allotment garden areas, localisation, as a means of preventing their expansion, plays an important role. This is also intended to decrease the social tensions that originated from conditions in previous areas. The equipment of allotment gardening and the individual allotment gardens themselves are most important in this aspect because they simultaneously demonstrate the central visual characteristics and also the activity's aesthetic perception. The users see their plots gardens as extensions of their homes, and therefore deposit items of furniture and materials no longer needed there. They build garden sheds from various materials, usually scrap. Extended periods of time spent at the plot garden, a consequence of users' perception of a plot garden as an extension of their home, require more equipment for the simple garden shed. There is an attempt to prevent this by forming and building uniform garden sheds, thus preventing individualised shed production. A uniform example of tool storage facilities on planned allotment garden areas will thus have an exemplary image in contrast to that which plot gardening has (mainly) had until now.

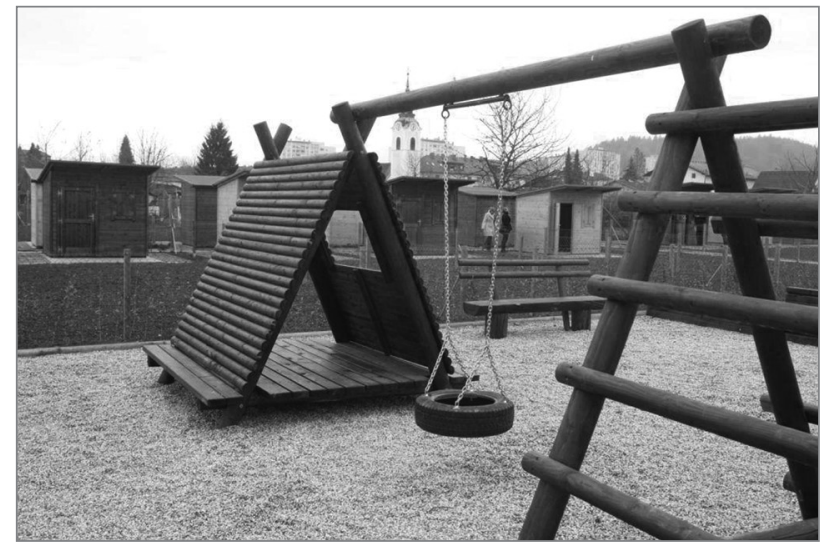

Figure 6: Sample allotment gardens in Štepanja Vas with playground equipment (photo: Miha Fras).

Cases from other countries often emphasise empty, abandoned and degraded areas being temporarily or permanently replaced by allotment gardens, improving the visual appearance of a neighbourhood. Allotment gardening has important advantages, in the sense of aesthetics, in its planned and regulated use. The city's image can be that of quality in the amount and organisation of the urban green spaces, including allotment gardens. In Ljubljana, the importance of an improved city image on account of allotment gardens will be seen only when the first regulated and equipped allotment areas are on lease and in use.
Considering that the purpose of allotment gardening is not only food production but also leisure time and recreational activity, the combination of that activity and other leisure-time activities is being emphasised. We now can find play areas and playground equipment, as seen in Figure 6. This creates an openness to visitors to the allotment-garden areas and increases their usefulness. The easiest and most effective way for the city to accomplish this is to provide regulations and thus enable and maintain a harmonious and aesthetic city image.

Allotment gardening increases the economic durability of cities and contributes to sustainable development. The aforementioned use of city waste as a productive solution in allotment gardening contributes to the decrease of city waste-management costs. The allotment gardens are important for highly urbanised metropolises, and we stress this based on the stabilisation and revitalisation of communities with allotment gardens because the value of the land can gradually increase (Petts, 2001). This fact is encouraging when city managers determine possible investment in allotment gardens. Communities with allotment gardens show a positive image. It is important that beautification of an area where informal activities such as plot gardening are taking place contribute to a better acceptance of the public, which then significantly influences the social relations. This can decrease certain negative effects such as, in this case, stigmatisation of the garden users and marginalisation of the activity.

\section{Conclusion}

When studying plot gardening as a social phenomenon, I approached this informal social activity from three different perspectives - the aspect of an individual, the environment and the city. From some perspectives, the latter two categories intertwine; however, significant characteristics of each can be recognised. Because the focus of this discussion is a sociological one, I have mainly concentrated on that social perspective. I believed it was important to stress that it is not only an individual or the society that gains from the encouragement or enabling of plot gardening, but the positive effects are also seen through the environment and the city as a spatial entity.

Considering the needs of urban residents, the planning of quality urban green spaces is a trend all over the world because this aspect significantly influences the quality of an individual's life. Plot gardening also has some advantages regarding the environment (namely, that it is important from the ecological point of view) and regarding the city (from aesthetic, economic and social points of view). A deeper understanding of plot gardening reveals not only the potential of greater food supply but also many other important aspects, aspects significant to social 
contexts and needing to be studied. Allotment gardening is not only comprised of food and food safety for those involved in the activity, but also social inclusion, solidarity, contact with nature and other important advantages for the individual. The wider significance relates to sustainable development, greening of cities through productive green areas, renovation of degraded portions of a city and creating a positive city image.

The greatest importance and essence of plot gardening is that its existence in the urban environment influences the local economy and environmental and social relations, and contributes to the diversity of a city. It may also work against these things and be the cause of health risks and destructive activities when resources are scarce. Due to those potential problems, regulation of the activity by the city authorities is absolutely necessary. Because plot gardening can satisfy psychological needs and needs for leisure time and recreation, it is important that the public and direct participants take part in the process of creating allotment-gardening regulations. I emphasise this because the plot-gardening issue in Ljubljana is comprised of very formalistic regulations, ones that cause dissatisfaction among the garden-plot users. It is a false presumption that increased supervision will result in greater compliance; instead, participation of the public in creating allotment-gardening regulations, which would result in less formalistic conditions, would cause greater compliance. This would originate from participants having a more positive perspective; namely, an attitude of shared responsibility towards the space, which would result in the integration of garden-plot users into the process of spatial transformation and creation of regulations.

In order to optimise the positive effects of plot gardening for the environment and the city, adequately equipped, suitable areas need to be chosen and the activity needs to be regulated. From individuals' perspective and that of their needs (mainly psychological and social needs), however, this condition is not absolutely necessary. These factors are intertwined and linked, so we cannot have healthy food without proper management of scarce resources and without professional determination of suitable and quality areas.

Karmen Bukvič

Videm pri Ptuju, Slovenia

E-mail: bukvic.karmen@gmail.com

\section{Notes}

[1] Space and environmental values (see Hočevar et al., 2004).

[2] One of the practical ideologies essential for understanding Slovenia, according to Rotar (1985), is "attachment to the home country", which he believes is one of the most anti-urban ideologies formed in the past due to the long period of the lack of a nation-state, and was intended as a social link and a mobilisation of social knowledge for the Slovenian people in the times of crises.

\section{References}

Bole, D., Breg Valjavec, M., Erhartič, B., Kladnik, D., Polajnar, K., \& Smrekar, A. (2009) Presoja primernosti načrtovanih vrtičkarskih območij $v$ Ljubljani [Assessing the suitability of planned garden-plot areas in Ljubljana]. Urbani izziv, 20(1), pp. 53-67 [175-189].

Bourque, M. (2000) Policy options for urban agriculture. Available at: http://www.trabajopopular.org.ar/material/Theme5.pdf (accessed 18 May 2009).

Chaplowe, S. G. (1996) Havana's popular gardens: Sustainable urban agriculture. Available at: http://www.cityfarmer.org/cuba.html (accessed 8 Dec. 2009).

Deelstra, T., \& Girardet, H. (2000) Urban agriculture and sustainable cities. Available at: http://www.trabajopopular.org.ar/material/ Theme2.pdf (accessed 18 May 2009).

Hlebec, V., \& Kogovšek, T. (2006) Merjenje socialnih omrežij. Ljubljana, Študentska založba.

Hočevar, M. (2000) Novi urbani trendi: Prizorišča v mestih - omrežja med mesti. Ljubljana, Univerza v Ljubljani, Fakulteta za družbene vede.

Hočevar, M., Kos, D., Verlič-Christensen, B., Trček, F., \& Uršič, M. (2004) Vrednote prostora in okolja. Research report. Ljubljana, Univerza v Ljubljani, Fakulteta za družbene vede, Center za prostorsko sociologijo.

Internet 1: http://www.ruaf.org/ (accessed 10 Nov. 2009).

Internet 2: http://www.ecocitybuilders.org/ (accessed 4 Jan. 2010).

Internet 3: http://www.ljubljana.si/si//zivljenje-v-ljubljani/v-srediscu/277/ detail.html (accessed 4 Jan. 2010).

Jacobi, P., Drescher, A. W., \& Amend, J. (2000) Urban agriculture - justification and planning guidelines. Available at: http://www. cityfarmer.org/uajustification.html (accessed 18 May 2009).

Jamnik, B., Smrekar, A., \& Vrščaj, B. (2009) Vrtičkarstvo v Ljubljani. Ljubljana, Založba ZRC.

Kos, D. (2007) Neurbana nacija. In: Čerpes, I., \& Dešman, M. (eds.): O urbanizmu, pp. 137-163. Ljubljana, Krtina.

Kos, D. (2008) Narava v mestu ali mesto v naravi? [Nature in the city or the city in nature?]. Urbani izziv, 19(2), pp. 5-9 [129-132].

Kučan, A. (1994) Zeleni sistem Ljubljane. Urbani izziv, 6(26-27), pp. 65-72.

Mlinar, Z. (1993) Prostorski nered kot izraz (ne) moči posameznika in sistema. Teorija in praksa, 30(5-6), pp. 427-434.

Mougeot, L. J. A. (2000) Urban agriculture: Definition, presence, potentials and risk. Available at: http://www.trabajopopular.org.ar/ material/Theme1.pdf (accessed 18 May 2009).

Nugent, R. (2000) The impact of urban agriculture on the household and local economies. Available at: http://www.trabajopopular.org.ar/ material/Theme3.pdf (accessed 18 May 2009). 
Odlok o urejanju in oddaji vrtičkov v zakup. Uradni list Republike Slovenije no. 28/2009. Ljubljana.

Petts, J. (2001) Urban agriculture in London. Available at: www.euro. who.int/document/e72421.pdf (accessed 8 Dec. 2009).

Pravilnik za urejanje območij vrtičkov v Mestni občini Ljubljana. Uradni list Republike Slovenije no. 83/2009. Ljubljana.

Rotar, D. B. (1981) Pomeni prostora: Ideologije v urbanizmu in arhitekturi. Ljubljana, Delavska enotnost.

Rotar, D. B. (1985) Risarji: učenjaki: Ideologije v urbanizmu in arhitekturi. Ljubljana, Delavska enotnost.

Simoneti, M. (1997) Mestne zelene površine: med ljubiteljstvom in stroko. Ljubljana, Znanstveno in publicistično središče.

Simoneti, M. (1998) Je mestne krajine potrebno varovati? [Should urban landscapes be protected?]. Urbani izziv, 9(2), pp. 45-50 [131-134].

Simoneti, M., Bevk, J. Pintar, M., Zupan, M., Gajšek, P., Golobič, M., et al. (1997) Usmeritve in pogoji za nadaljnji razvoj vrtičkarstva $v$ Ljubljani. Research report. Ljubljana, Ljubljanski urbanistični zavod.

Smit, J., Ratta, A., \& Nasr, J. (1996) Urban agriculture: Food, jobs and sustainable cities. New York, UNDP.

Smrekar, A. (2007) Stihijski (ne) razvoj neurbaniziranega dela mesta na primeru Ljubljane. Dela, 28, pp. 341-357.

Tsubota, K. (2007) Urban agriculture in Asia: Lessons from Japanese experience. Available at: http://www.agnet.org/library/eb/576/ (accessed 8 Dec. 2009)

Ule, M. (1998) Stilizacija vsakdanjega življenja. Družboslovne razprave, $14(27-28)$, pp. 26-32.

Uršič, M., \& Hočevar, M. (2007) Protiurbanost kot način življenja. Ljubljana, Univerza v Ljubljani, Fakulteta za družbene vede.

Vastl, N. (2000) Vrtičkarstvo. Certificate thesis. Ljubljana, Univerza v Ljubljani, Fakulteta za arhitekturo. 